\title{
Morphometric variation of the horseshoe crab Tachypleus gigas (Xiphosura: Limulidae) from the Banyuasin estuarine of South Sumatra, Indonesia
}

\author{
FAUZIYAH $^{1, \bullet}$, APON Z. MUSTOPA ${ }^{2}$, FATIMAH $^{3}$, ANNA I. S. PURWIYANTO ${ }^{1}$, ROZIRWAN $^{1}$, \\ FITRI AGUSTRIANI ${ }^{1}$, WIKE A. E. PUTRI ${ }^{1}$ \\ ${ }^{1}$ Department of Marine Science, Faculty of Mathematics and Natural Sciences, Universitas Sriwijaya. Jl. Raya Palembang-Prabumulih Km. 32, Indralaya, \\ Ogan Ilir 30862, South Sumatra, Indonesia. Tel. +62-711-580056, Fax. +62-711-580268, `email: siti_fauziyah@yahoo.com \\ ${ }^{2}$ Research Center for Biotechnology, National Research and Innovation Agency. Jl. Raya Jakarta-Bogor Km 46, Cibinong, Bogor 16911, West Java, \\ Indonesia \\ ${ }^{3}$ Indonesian Center for Agricultural Biotechnology and Genetic Resources Research and Development. Jl. Tentara Pelajar, Cimanggu, Bogor 16111, \\ Indonesia
}

Manuscript received: 19 September 2021. Revision accepted: 26 October 2021.

\begin{abstract}
Fauziyah, Mustopa AZ, Fatimah, Purwiyanto AIS, Rozirwan, Agustriani F, Putri WAE. 2021. Morphometric variation of the horseshoe crab Tachypleus gigas (Xiphosura: Limulidae) from the Banyuasin estuarine of South Sumatra, Indonesia. Biodiversitas 22: 5061-5070. Morphological studies are essential for fish resource management, ecology, conservation, and stock assessment. This research was conducted to characterize the morphological variation of the coastal horseshoe crab (Tachypleus gigas) from the Banyuasin estuarine, South Sumatra, Indonesia. The body weight (BW), prosoma width (PW), carapace length (CL), telson length (TEL), and total length (TL) were measured for describing the morphometric variability of T. gigas. A total of 70 T. gigas (32 females and 38 males) were found using trammel net fishing and bottom gillnet during the survey. Multivariate and allometric methods analyzed their morphometric characters. Based on Kruskal- Wallis tests, the result showed a significant difference in somebody measurements (TL and CL) between males and females. The principal component analysis (PCA) results showed that all morphometric characters had a strong correlation in both sexes, so the first principal component (PC1) values were $92 \%$ and $72 \%$. In comparison, the second principal component (PC2) values were 5\% and $20 \%$ in females and males, respectively. The results of discriminant function analysis (DFA) suggested that only one (BW) of the five morphometric characters was significant in separating both sexes. Both sexes were also revealed variations in growth patterns based on the allometric analysis results. These results were expected to be used as a basis for managing the horseshoe crab population-based conservation.
\end{abstract}

Keywords: Allometric, arthropod, body measurements, conservation, growth pattern, morphometric characters

\section{INTRODUCTION}

Many researchers have explained an essential of the morphometric study as well as the allometric studies for assessing the growth characteristics, body shape changes, population diversity of organisms and its related to their ecosystems condition (Chiu and Morton 2001; Webster 2007; Srijaya et al. 2010; Syuhaida et al. 2019). These morphological structure variations helped study the classification and identification of various species. In contrast, the allometric studies could usefully evaluate the variation in the body part parameters of species living in multiple ecosystems (Srijaya et al. 2010). The allometric study of horseshoe crabs played a key role in understanding the comparative of morphometric and growth in various body parameters (Chatterji et al. 1988). Additionally, the changes in the maturity stage, genetics, diet, in-situ physical-chemicals parameters, and habitat influenced the size variation of horseshoe crab (Gaspar et al. 2000; Graham et al. 2009; Jawahir et al. 2017). Hence, the allometric analysis would contribute to assessing the relationship between morphological parameters of horseshoe crabs and ecosystems.
Habitats of Asian horseshoe crabs [Tachypleus tridentatus (Leach, 1819), Tachypleus gigas (Müller, 1785) and Carcinoscorpius rotundicauda (Latreille, 1802)] are diminishing, and even their populations are declining (Cartwright-Taylor et al. 2011; Biswal et al. 2016; Pati et al. 2021). In Hong Kong, T. gigas are currently considered locally extinct (Lee and Morton 2005). In Singapore, $T$. gigas is now classified as endangered due to habitat loss (Cartwright-Taylor et al. 2011). Disturbances of humans also contribute to the habitat loss of T. gigas in India (Pati et al. 2015).

In Indonesian waters, T. gigas are found in Muara Badak waters of Kutai Kartanegara, East Kalimantan (Ahmad et al. 2017) and distributed along the Java Northern Coast and Madura Southern Coast (Meilana et al. 2016; Mashar et al. 2017). Tachypleus gigas are found in Kuala Tungkal waters of Tanjung Jabung Barat, Jambi (Rubiyanto 2012) and found in Banyuasin estuarine (Fauziyah et al. 2019a). In addition, this species is also found in Maluku waters (Dolejš and Vaňousová 2015; John et al. 2018), and then no scientific record on the occurrence of T. gigas in other waters of Indonesia. In Indonesia, the horseshoe crabs were found as discard or by-catch and 
were not an essential fishery (Fauziyah et al. 2018; John et al. 2018). However, recently, these horseshoe crabs underprotected animals according to the decree of the Ministry of Environment and Forestry No. P.20/2018 on protected plants and animals. Additionally, the International Union for Conservation of Nature (IUCN) Red List assessment on T. gigas listed these species under "Data Deficient" (World Conservation Monitoring Centre 1996). One of the IUCN considerations to maintain this "Data Deficient" status is the lack of field data from Asian researchers (Nelson et al. 2019).

In the Banyuasin estuarine waters (South Sumatra) are found two horseshoe crabs, T. gigas and C. rotundicauda (Fauziyah et al. 2019a). In the first investigation (Fauziyah et al. 2019a), such a small amount of $T$. gigas (11 specimens) was found, not defined in morphometric variability. Nowadays, information about $T$. gigas in the Banyuasin waters is scarce. Hence, further investigations were needed. Cartwright-Taylor et al. (2011) stated that quantitative data are necessary to assign conservation status, monitor population threats, and confirm protection actions for this species.

The present study aimed to apply the allometric relationships to describe the morphometric variability for $T$. gigas obtained from Banyuasin estuarine waters. In addition, these results were expected to be used as a basis for managing the horseshoe crab population-based conservation.

\section{MATERIALS AND METHODS}

\section{Study area}

The study was conducted in the Banyuasin estuarine of South Sumatra, Indonesia (Figure 1) from July 2019 to August 2021.

\section{Data collection}

No permits were required for the morphometric measurements of $T$. gigas. In the present study, 70 samples of T. gigas (32 females and 38 males) were obtained during sampling. The samples were found in three main locations, namely Makarti Jaya, Tanjung Carat, and Berbak Sembailang National Park. Sampling took place in July, November, and December 2019 found 11, 15, and 2 samples, respectively. During October 2020, only 4 samples were found, whereas sampling in January, March, July, and August 2021, 5, 16, 6 , and 11 samples were found. The samples were collected using trammel net fishing and bottom gillnet that operated from 05:00 am to 14:00. Determining the sampling location referred to the previous survey (Fauziyah et al. 2019a) and the information of local fishers. All sample measurements were conducted on the fish landing site due to difficulties if the measurements were conducted on board. To avoid catching the same sample twice on different occasions, the samples were marked and released at Payung Island (5,158 $\mathrm{km}$ from the nearest sampling site) and Sembilang River (7,092 km from the nearest sampling site).
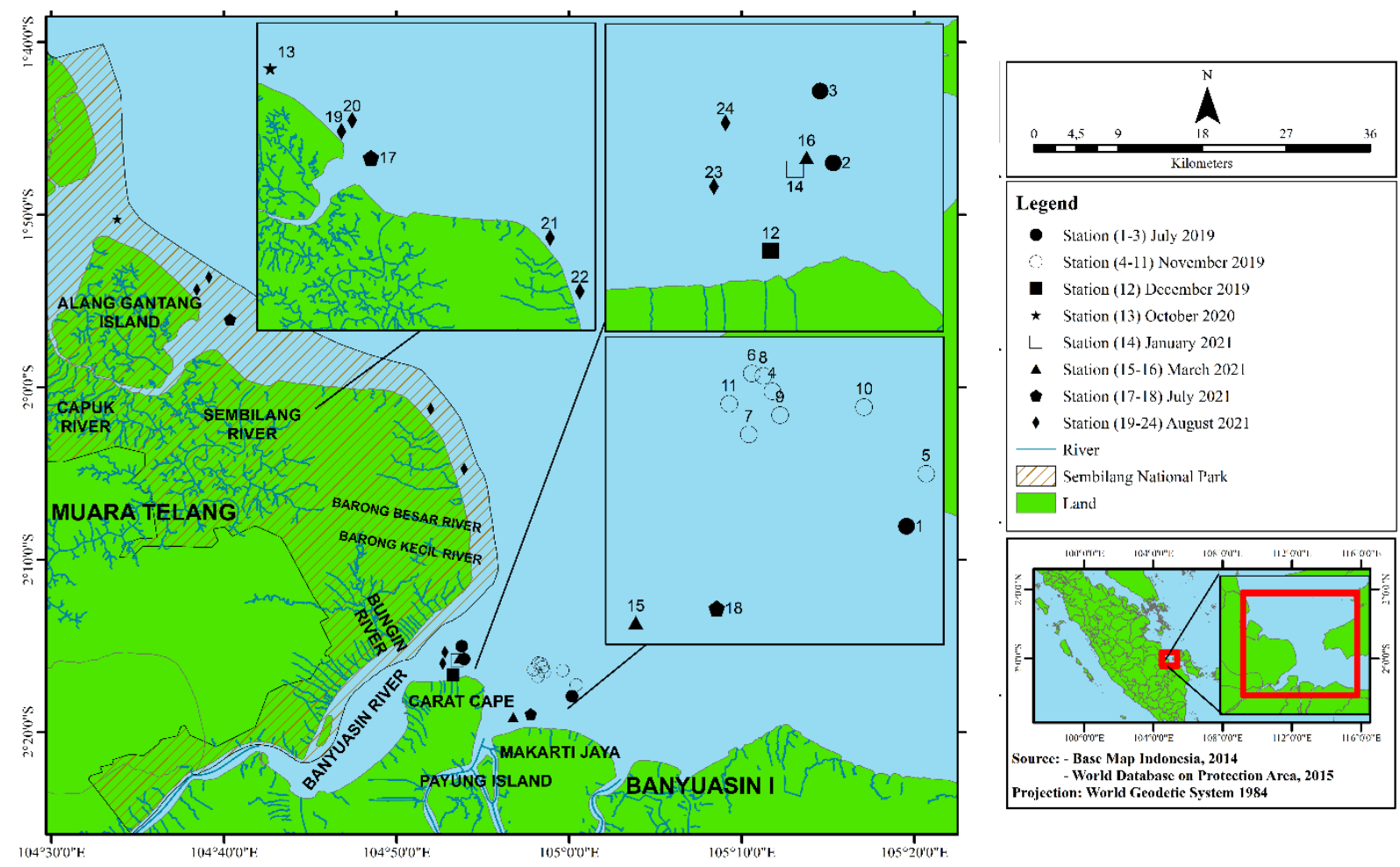

Figure 1. The sampling sites map of the horseshoe crab (Tachypleus gigas) in the Banyuasin estuarine of South Sumatra, Indonesia 


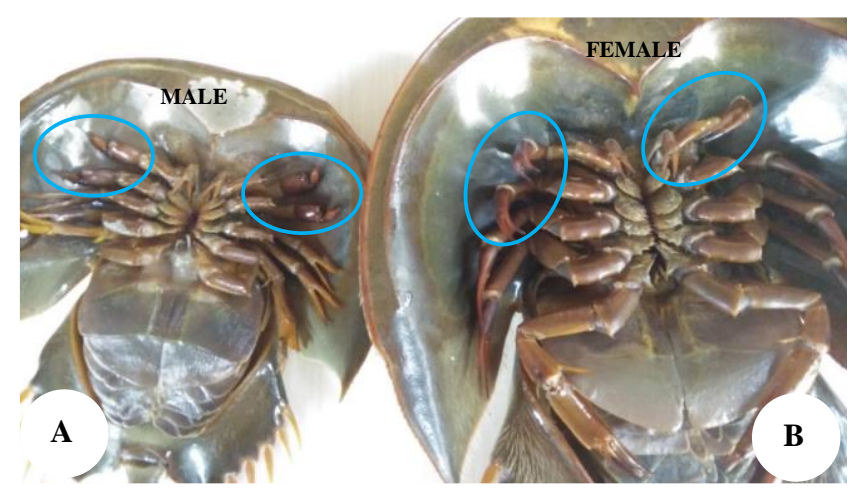

Figure 1. The differences in body parts of male and female for Tachypleus gigas species. The male (A) has hemichelate clasperlike hooks while the female (B) has chelate clasper-like scissors

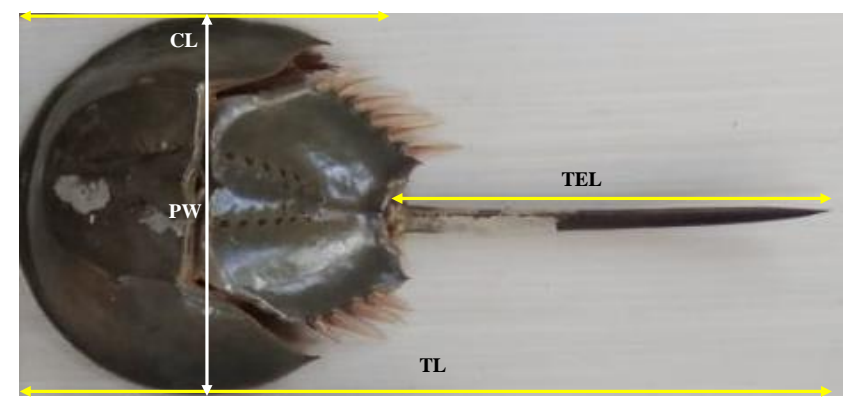

Figure 2. The major morphometric measurement of the horseshoe crab Tachypleus gigas consists of prosoma width (PW), carapace length (CL), telson length (TEL), and total length (TL). All body parameters were recorded to $1 \mathrm{~mm}$ accuracy.

Identification refers to the previous study conducted in Banyuasin estuarine (Fauziyah et al. 2019a). For $T$. gigas, their cross-section morphology of the telson is a triangle shape with only has one spine on the rear part of the opisthosoma, whereas $T$. tridentatus besides has a triangle shape of the telson (similarly to $T$. gigas), there is three spines on the rear part of the opisthosoma (only one spine for $T$. gigas) and many tiny spines on opisthosoma (back carapace) than others (Cartwright-Taylor et al. 2009; 2011; Tanacredi et al. 2009; Dolejš and Vaňousová 2015). On the other hand, $C$. rotundicauda is easy to distinguish due to the cross-section morphology of the telson being a rounded shape (Yang and Ko 2015). Furthermore, the clasper shape on the first and second walking legs is used to distinguish between males and females (Figure 2) due to hemichelate clasper-like hooks, which only occur in the male while chelate clasper-like scissors belong to the female (Fauziyah et al. 2019a,b). The prosoma width (PW), carapace length (CL), telson length (TEL), and total length (TL) were measured to $1 \mathrm{~mm}$ accuracy (Figure 3), while body weight (BW) was weighted to 1 gram accuracy.

\section{Data analysis}

All measurements data were pooled according to females and males then inserted into Microsoft Excel. These data were transformed using a square root (Mohamed et al. 2021). The Kolmogorov-Smirnov test was applied to verify a normal distribution. When most of the parameters did not show a normal distribution, the nonparametric test (Kruskal-Wallis test) was performed to compare each morphometric parameter for both sexes. This study performed principal component analysis (PCA) and discriminant function analysis (DFA) to assess the significant differences of all parameters among sexes.

The power equation was applied to analyze the lengthweight relationship (Le Cren 1951; Froese 2006; Graham et al. 2009; Jawahir et al. 2017), while the linear equation was used to analyze the length-length/width relationship (Chiu and Morton 2001; Aydin and Aydin 2011; Amaral et al. 2014; Ming et al. 2016). For achieving a better fit of the regression model, an outlier will be removed from the data set (Manimannan et al. 2020). The formulas for these equations are as follows:

$$
W_{i}=a L_{i}^{b}
$$

Where: $W_{i}$ : bodyweight of the horseshoe crab i, $L_{i}$ : length parameter of the horseshoe crab i, $a$ : intercept of the relationship between $\ln L_{i}$ and $\ln W_{i}, b$ : the slope of the relationship between $\ln L_{i}$ and $\ln W_{i}$.

$$
Y_{i}=a+b X_{i}
$$

Where: $Y_{i}$ : one length parameter of the horseshoe crab i, $X_{i}$ : a random rest length parameter of the horseshoe crab i, $a$ : intercept of the relationship between $\ln Y_{i}$ and $\ln X_{i}, b$ : the slope of the relationship between $\ln X_{i}$ and $\ln Y_{i}$.

In the term of the TEL-TL, PW-TL, and PW-CL relationships (Amaral et al. 2014; Ming et al. 2016), the b value $<1$ indicated that $\mathrm{Y}$-axis (PW, LT) grew relatively slower than $\mathrm{X}$-axis (TL, CL) and it's called a negativeallometric growth, whilst the $\mathrm{b}$ value $>1$ indicated $\mathrm{a}$ positive-allometric growth and the $b$ value $=1$ indicated an isometric growth. Due to the dimensions of $\mathrm{X}$ and $\mathrm{Y}$ were not the same at the length-weight relationships (BW-PW, BW-TL, BW-CL) hence called a negative-allometric growth when the $\mathrm{b}$ value $<3$, whereas the $\mathrm{b}$ value $>3$ indicated a positive-allometric growth and the $\mathrm{b}$ value $=3$ indicated an isometric growth. Thus the $b$ value indicates a growth pattern (Syuhaida et al. 2019). For determining significant differences from the isometric value $(b=3$ or $b$ $=1$ ), Bailey's t-test was applied with the significant level at 5\% (Thomas 2013; Hegele-Drywa et al. 2014; Nair et al. 2015).

$$
t_{s}=\left|\frac{3-b}{s b}\right| \text { or } t_{s}=\left|\frac{1-b}{s b}\right|
$$

Where: $t_{s}$ : Bailey's t-test, $b$ : the slope of the linear regression, $\mathrm{Sb}$ : standard error of the $\mathrm{b}$ coefficients, 3: isometric value of the length-weight relationships, and 1: isometric value of the length-length-relationships. 


\section{RESULTS AND DISCUSSION}

\section{Body parameters measurements}

The mean of the significant body parameters of $T$. gigas by sex and their normality test are presented in Table 1 , while testing the difference in body parameters for both sexes was shown in Table 2 . The females body parameters (BW, CL, TEL, TL, and PW) were higher than males (Table 1). However, statistically (Table 2), there was a significant difference between males and females for TL and CL $(p>0.05)$ based on Kruskal-Wallis tests.

\section{Morphometric characters}

Bartlett's test was performed to verify the data adequacy for PCA, and the result was significant (P-value $<0.05)$. To determine the morphometric characters that most effectively differentiate between the sexes, the characters' contributions to PCA were examined (Table 3). The PCA results of 5 morphometric characters reduced one factor in both sexes with eigenvalues exceed than 1 . The first principal component (PC1) values were $92 \%$ and $72 \%$, while the second principal component (PC2) values were $5 \%$ and $20 \%$ in females and males, respectively.

Table 1. The normality test results of the body parameters data by sex using the Kolmogorov-Smirnov Test. The values of Asymp. Sig. (2-tailed) $>0.05$ indicated a normal distribution

\begin{tabular}{|c|c|c|c|c|c|}
\hline \multirow{2}{*}{ Statistic parameters } & \multicolumn{5}{|c|}{ The major body parameters } \\
\hline & BW (g) & CL (mm) & TEL (mm) & TL (mm) & PW (mm) \\
\hline \multicolumn{6}{|l|}{ All $(\mathrm{N}=70)$} \\
\hline Mean & 376.1 & 16.7 & 17.4 & 34.0 & 17.1 \\
\hline Standard Deviation & 240.7 & 3.4 & 3.4 & 6.2 & 3.2 \\
\hline Coefficient of Variation & 0.6 & 0.2 & 0.2 & 0.2 & 0.2 \\
\hline Kolmogorov-Smirnov & 0.7 & 0.8 & 1.4 & 1.2 & 1.0 \\
\hline Asymp. Sig. (2-tailed) & $0.70^{\mathrm{N}}$ & $0.52^{\mathrm{N}}$ & 0.04 & $0.10^{\mathrm{N}}$ & $0.26^{\mathrm{N}}$ \\
\hline \multicolumn{6}{|l|}{ Males $(\mathbf{N}=38)$} \\
\hline Mean & 291.5 & 15.9 & 16.7 & 32.7 & 16.6 \\
\hline Standard Deviation & 122.6 & 2.0 & 3.0 & 4.3 & 2.4 \\
\hline Coefficient of Variation & 0.4 & 0.1 & 0.2 & 0.1 & 0.1 \\
\hline Kolmogorov-Smirnov & 0.7 & 0.9 & 1.6 & 1.4 & 1.2 \\
\hline Asymp. Sig. (2-tailed) & $0.76^{\mathrm{N}}$ & $0.33^{\mathrm{N}}$ & 0.01 & 0.04 & $0.14^{\mathrm{N}}$ \\
\hline \multicolumn{6}{|l|}{ Females $(\mathrm{N}=32)$} \\
\hline Mean & 476.5 & 17.6 & 18.1 & 35.6 & 17.8 \\
\hline Standard Deviation & 300.5 & 4.3 & 3.7 & 7.5 & 3.9 \\
\hline Coefficient of Variation & 0.6 & 0.2 & 0.2 & 0.2 & 0.2 \\
\hline Kolmogorov-Smirnov & 0.6 & 0.6 & 0.5 & 0.6 & 0.6 \\
\hline Asymp. Sig. (2-tailed) & $0.86^{\mathrm{N}}$ & $0.90^{\mathrm{N}}$ & $0.96^{\mathrm{N}}$ & $0.90^{\mathrm{N}}$ & $0.92^{\mathrm{N}}$ \\
\hline
\end{tabular}

Note: BW: body weight, CL: carapace length, TEL: telson length, TL: total length, PW: prosoma width, The significance level $(\alpha)$ of $0.05,{ }^{N}$ : normal distribution

Table 2. The different body parameters of Tachypleus gigas by sex using the Kruskal-Wallis test. The $P$-value is greater than 0.05 indicated no significant difference in body parameters between males and females

\begin{tabular}{|c|c|c|c|c|c|c|c|}
\hline \multirow{2}{*}{$\begin{array}{l}\text { Body } \\
\text { parameters }\end{array}$} & & Males & & & Femal & & \multirow{2}{*}{$\begin{array}{c}\text { Kruskal- } \\
\text { Wallis test } \\
\text { (Males vs } \\
\text { Females) } \\
P \text {-values }\end{array}$} \\
\hline & Min & Max & Mean & Min & Max & Mean & \\
\hline BW (g) & 81 & 865 & 291.5 & 67 & 1,100 & 476.5 & $0.111^{\mathrm{NS}}$ \\
\hline $\mathrm{CL}(\mathrm{mm})$ & 110 & 220 & 159.2 & 90 & 240 & 175.5 & $0.047^{\mathrm{S}}$ \\
\hline TEL (mm) & 70 & 210 & 167.4 & 100 & 245 & 181.0 & $0.103^{\mathrm{NS}}$ \\
\hline TL (mm) & 215 & 430 & 326.6 & 198 & 140 & 356.3 & $0.024^{\mathrm{S}}$ \\
\hline PW (mm) & 80 & 215 & 165.7 & 100 & 244 & 177.7 & $0.088^{\mathrm{NS}}$ \\
\hline
\end{tabular}

Note: BW: body weight, CL: carapace length, TEL: telson length, TL: total length, PW: prosoma width, S: significant difference, NS: no significant difference, $\alpha$ : 0.05
Table 3. Summary results of PCA for morphometric characters between sexes in the Tachypleus gigas from the Banyuasin estuarine, South Sumatra, Indonesia

\begin{tabular}{lrrrr}
\hline \multirow{2}{*}{ Variable } & \multicolumn{2}{c}{ Female } & \multicolumn{2}{c}{ Male } \\
\cline { 2 - 5 } & \multicolumn{1}{c}{ PC1 } & \multicolumn{1}{c}{ PC2 } & \multicolumn{1}{c}{ PC1 } & \multicolumn{1}{c}{ PC2 } \\
\hline \multirow{2}{*}{ Eigenvalue } & 4.5963 & 0.2357 & 3.6137 & 0.9843 \\
Proportion & $92 \%$ & $5 \%$ & $72 \%$ & $20 \%$ \\
Cumulative & $92 \%$ & $97 \%$ & $72 \%$ & $92 \%$ \\
BW & $0.44^{*}$ & -0.277 & $0.446^{*}$ & -0.234 \\
CL & $0.452^{*}$ & -0.371 & $0.49^{*}$ & -0.289 \\
TEL & 0.429 & $0.799^{*}$ & 0.364 & $0.724^{*}$ \\
TL & $0.462^{*}$ & 0.202 & $0.489^{*}$ & 0.365 \\
PW & $0.453^{*}$ & -0.325 & 0.435 & $-0.451^{*}$ \\
\end{tabular}

Note *: most significant loadings on each component 


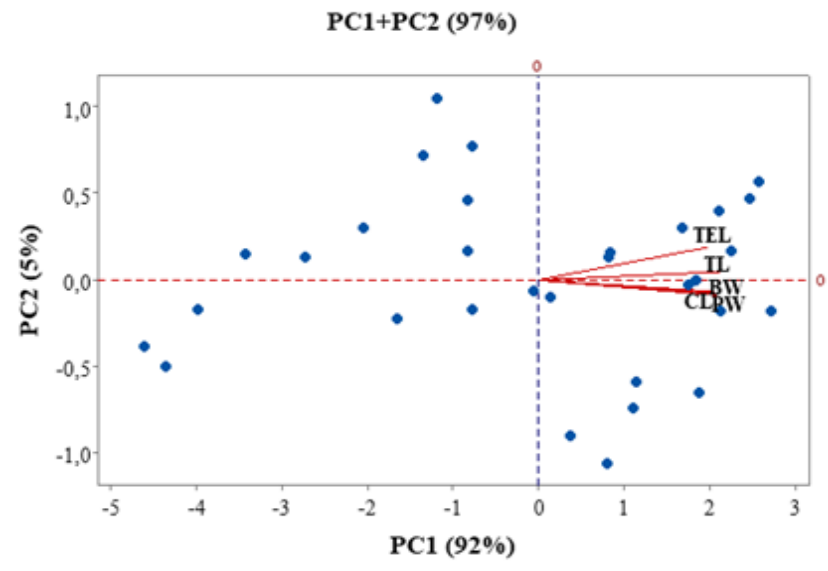

A

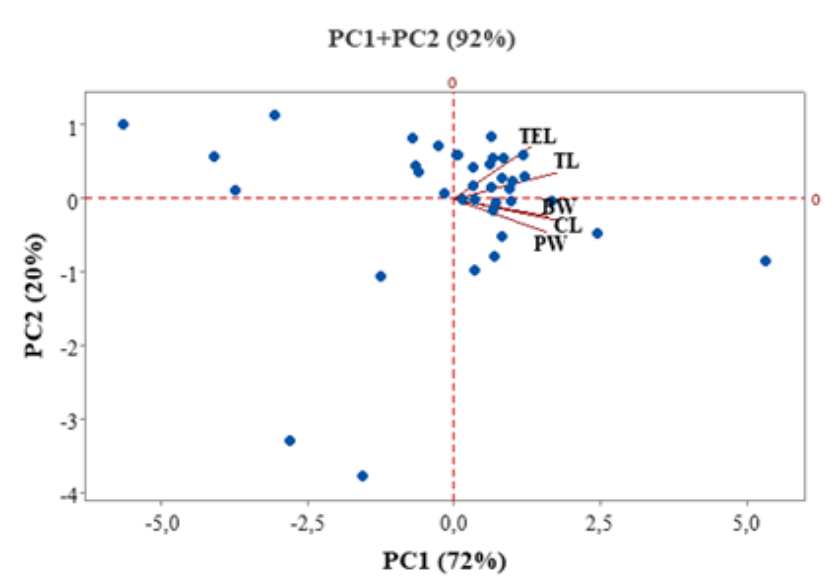

$\mathbf{B}$

Figure 3. The PCA biplot of the morphometric characters data in different sexes of Tachypleus gigas from the Banyuasin estuarine, South Sumatra, Indonesia. A. Female, B. Male

The most significant loadings on PC1 in females were BW, CL, TL, and PW, as well as in males, BW, CL, and TL (Table 3). Whereas the most significant loadings on PC2 in males were TEL and PW, and only TEL was most significant in females. In this analysis, a factor loading greater than 0.40 is considered significant. The PCA biplot (Figure 4) showed that BW, CL, TEL, TL, and PW were positively correlated and highlighted the importance in both sexes based on PC1. According to the PC2, some parameters (BW, CL, and $\mathrm{PW}$ ) indicated a negative correlation in both sexes. However, all morphometric characters strongly correlated with each other in both sexes (the angle between characters was less than 90\%). The PC1 also indicated the strength of the correlation with eigenvalues exceeding 1 (Table 3 ).

Based on the DFA results Table 4, a stepwise method suggested that only one (BW) of the five morphometric characters were significant in separating the both sexes (Eigenvalue $=0.117 ;$ Wilks' Lambda $=0.895 ; \mathrm{df}=1 ; \mathrm{P}<$ 0.05 ). The centroid values for females and males were 0.367 and -0.309 , respectively. The cutoff score (the centroid average) was 11.6. It means that if the discriminant function values exceed 13.8 are classified as females. Otherwise, the values below 11.6 are classified as males. The DFA in sexes gave an average percentage of correctly classified (PCC) of $68.6 \%$ into their original morphometric characters (Table 5). In addition, the crossvalidation test was the same as the PCC results of their original morphometric characters.

\section{Morphometric allometry}

The parameters of the allometric analysis for $\mathrm{T}$. gigas by sex are presented in Table 5 and Figure 5-6. Generally, all relationships between each body parameter indicated variation in the coefficient of determination ( $\mathrm{R} 2$ ranged between 0.69 to 0.95 ). In addition, there were variations in the number of data set (Figure 5 and 6) due to removing a few outliers to avoid an unsatisfactory model performance (the $\mathrm{R} 2 \leq \mathrm{0.65}$ ). Variation in the allometric value (b) ranged between 2.1 to 3.3 for the weight-length relationships, while length-length relationships ranged between 0.6 to 1.2 . These values indicated variation in growth patterns such as negative allometric or isometric, depending on the student's t-test results.

The weight-length relationships indicated that the BW parameter grew proportional to the CL, TEL, and TL parameters for both sexes. These relationships indicated an isometric growth pattern $\left(t_{s}<t_{t a b}, p<0.05\right)$. Whereas the males BW parameter grew relatively slower than the PW parameter (negative allometric, $\mathrm{b}<3, \mathrm{t}_{\mathrm{s}}>\mathrm{t}_{\mathrm{tab}}, \mathrm{p}<0.05$ ) but both parameters exhibited an isometric growth pattern for females.

Table 4. Summary results of DFA for different morphometric characters between sexes in the Tachypleus gigas from the Banyuasin estuarine, South Sumatra, Indonesia

\begin{tabular}{ll}
\hline Statistical parameters & Results \\
\hline $\begin{array}{l}\text { Fisher's linear discriminant functions: } \\
\text { Females }\end{array}$ & $\mathrm{D}_{1}=0.648 \mathrm{BW}-7.347$ \\
$\quad$ Males & $\mathrm{D}_{2}=0.527 \mathrm{BW}-5.108$ \\
$\begin{array}{l}\text { Functions at group centroids: } \\
\text { Females }\end{array}$ & 0.367 \\
Males & -0.309 \\
Cut-off & 11.6 \\
Canonical discriminant function & $\mathrm{D}=0.177 \mathrm{BW}-3.281$ \\
Wilks' Lambda test (P-value) & $0.006^{*}$ \\
Accuracy of sex discriminant in the & \\
original morphometric characters: & \\
Females & $53.1 \%$ \\
Males & $81.6 \%$ \\
$\begin{array}{l}\text { Overall } \\
\text { Accuracy of sex discriminant in the } \\
\text { cross-validation test }\end{array}$ & $68.6 \%$ \\
$\quad$ Females & \\
Males & \\
Overall & $53.1 \%$ \\
\hline
\end{tabular}

Note: *Significant difference in the morphometric characters between sexes 
Table 3. The body parameters relationships and growth pattern for Tachypleus gigas by sex. The value of $t_{s}<t_{\text {tab }}$ indicated isometric growth while $t_{s}>t_{\text {tab }}$ indicated allometric growth

\begin{tabular}{|c|c|c|c|c|c|c|c|c|c|}
\hline \multirow{2}{*}{$\begin{array}{l}\text { Body parameters } \\
\text { relationships (Y-X) }\end{array}$} & \multicolumn{5}{|c|}{ Parameters of the relationship } & \multicolumn{3}{|c|}{ Bailey's t-test } & \multirow{2}{*}{ Growth pattern } \\
\hline & $\mathbf{b}$ & Sb & $\mathbf{t}_{\mathrm{b}}$ & P-valus & $\mathbf{R}^{2}$ & $\beta$ & $t_{\text {tab }}$ & $\mathbf{t}_{\mathrm{s}}$ & \\
\hline \multicolumn{10}{|l|}{ Males } \\
\hline BW-PW & 2.118 & 0.201 & 10.551 & $<0.001$ & 0.811 & 3 & 2.056 & $4.397^{\mathrm{S}}$ & Allometric (-) \\
\hline BW-CL & 3.062 & 0.264 & 11.616 & $<0.001$ & 0.808 & 3 & 2.037 & $0.236^{\mathrm{NS}}$ & Isometric \\
\hline BW-TEL & 3.293 & 0.332 & 9.923 & $<0.001$ & 0.761 & 3 & 2.040 & $0.884^{\mathrm{NS}}$ & Isometric \\
\hline BW-TL & 3.089 & 0.288 & 10.733 & $<0.001$ & 0.777 & 3 & 2.035 & $0.308^{\mathrm{NS}}$ & Isometric \\
\hline PW-CL & 0.934 & 0.083 & 11.240 & $<0.001$ & 0.783 & 1 & 2.069 & $0.800^{\mathrm{NS}}$ & Isometric \\
\hline PW-TEL & 1.067 & 0.157 & 6.780 & $<0.001$ & 0.667 & 1 & 2.069 & $0.427^{\mathrm{NS}}$ & Isometric \\
\hline TL-PW & 1.302 & 0.111 & 11.771 & $<0.001$ & 0.817 & 1 & 2.040 & $2.729^{\mathrm{S}}$ & Allometric (+) \\
\hline TL-CL & 1.692 & 0.136 & 12.465 & $<0.001$ & 0.820 & 1 & 2.032 & $5.097^{\mathrm{S}}$ & Allometric (+) \\
\hline TEL-CL & 0.809 & 0.088 & 9.176 & $<0.001$ & 0.757 & 1 & 2.052 & $2.164^{\mathrm{S}}$ & Allometric (-) \\
\hline TEL-TL & 0.496 & 0.035 & 14.329 & $<0.001$ & 0.858 & 1 & 2.032 & $14.551^{\mathrm{S}}$ & Allometric (-) \\
\hline \multicolumn{10}{|l|}{ Females } \\
\hline BW-PW & 3.078 & 0.205 & 15.033 & $<0.001$ & 0.883 & 3 & 2.042 & $0.381^{\mathrm{NS}}$ & Isometric \\
\hline BW-CL & 2.702 & 0.199 & 13.596 & $<0.001$ & 0.860 & 3 & 2.042 & $1.498^{\mathrm{NS}}$ & Isometric \\
\hline BW-TEL & 3.162 & 0.263 & 12.019 & $<0.001$ & 0.838 & 3 & 2.048 & $0.617^{\mathrm{NS}}$ & Isometric \\
\hline BW-TL & 3.245 & 0.209 & 15.555 & $<0.001$ & 0.890 & 3 & 2.042 & $1.176^{\mathrm{NS}}$ & Isometric \\
\hline PW-CL & 0.876 & 0.044 & 20.012 & $<0.001$ & 0.930 & 1 & 2.042 & $2.836^{\mathrm{S}}$ & Allometric (-) \\
\hline PW-TEL & 0.900 & 0.078 & 11.532 & $<0.001$ & 0.836 & 1 & 2.056 & $1.280^{\mathrm{NS}}$ & Isometric \\
\hline TL-PW & 1.774 & 0.126 & 14.106 & $<0.001$ & 0.869 & 1 & 2.042 & $6.155^{\mathrm{S}}$ & Allometric (+) \\
\hline TL-CL & 1.634 & 0.103 & 15.874 & $<0.001$ & 0.894 & 1 & 2.042 & $6.158^{\mathrm{s}}$ & Allometric (+) \\
\hline TEL-CL & 0.796 & 0.075 & 10.555 & $<0.001$ & 0.805 & 1 & 2.052 & $2.699^{\mathrm{s}}$ & Allometric (-) \\
\hline TEL-TL & 0.467 & 0.030 & 15.407 & $<0.001$ & 0.888 & 1 & 2.042 & $17.564^{\mathrm{S}}$ & Allometric (-) \\
\hline
\end{tabular}

Note: BW: body weight, CL: carapace length, TEL: telson length, TL: total length, PW: prosoma width, Sb: standard error of the b coefficients, Sig. F: significance F-test, $\mathrm{R}^{2}$ the coefficient of determination, $\mathrm{t}_{\mathrm{b}}$ : the $\mathrm{t}$-test statistic for $\mathrm{H}_{0}$ of $\mathrm{b}$ : 0 , $\beta$ : allometric value, $\mathrm{t}_{\mathrm{tab}}$ : critical values of the $t$ distribution, $t_{\mathrm{s}}$ : Bailey's t-test for allometric values, S: Significant, and NS: Not significant

In the length-length relationships, the PW-TEL relationship for both sexes showed an isometric growth pattern $\left(\mathrm{t}_{\mathrm{s}}<\mathrm{t}_{\mathrm{tab}}, \mathrm{p}<0.05\right)$. The $\mathrm{PW}-\mathrm{CL}$ relationship indicated negative allometric growth for females but an isometric growth pattern for males. Positive allometric growth was exhibited by the TL-PW dan TL-CL relationships for both sexes $\left(b>1, t_{s}>t_{t a b}, p<0.05\right)$. These relationships indicated that the TL parameter increased relatively faster than the PW or CL parameter. Conversely, the TEL-CL and TEL-TEL relationships for both sexes described a negative allometric growth.

\section{Discussion}

The number of samples obtained in this study was only 70 and may not be too greater than a similar study in Balaramgari of Orissa, India (Vijayakumar et al. 2000) and Sarawak waters of East Malaysia (Jawahir et al. 2017). But the samples are still worthy of being used as a predictive tool as their allometric model indicated a good model performance $(\mathrm{R} 2>0.65)$. Based on previous research (Fauziyah et al. 2019a), the ratio of $C$. rotundicauda to $T$. gigas was 1: 4. This is probably because of the sampling location, which was muddy seafloor and close to mangroves, so it is more favorable for $C$. rotundicauda. Meanwhile, T. gigas prefers the waters with sandy seafloor (Tan et al. 2012). Low abundance was found for $T$. gigas, making sampling difficult. This is also consistent with Cartwright-Taylor et al. (2011), who stated that the critical situation in the main island of Singapore for T. gigas and historical data were not recorded. The first record of $T$. gigas from Banyuasin estuarine, South Sumatra of Indonesia, has been published since 2019 (Fauziyah et al. 2019a). However, no information in detail to the morphometric variability. This study's results provided the data and information on the morphometric of T. gigas for complementing the previous study. Many researchers analyzed the body allometry for $T$. gigas obtained from the different populations in Malaysia or India waters (Chatterji et al. 1994; Vijayakumar et al. 2000; Ismail et al. 2012; Jawahir et al. 2017; Razak and Kassim 2018). Compared with observation in Malaysia (Jawahir et al. 2017; Razak and Kassim 2018), the major body parameters of T. gigas in this study tended to attain smaller sizes for both sexes.

The body allometric (growth pattern) of this horseshoe crab could be described by the relationship between one body parameter and the other (Panda and Naik 2017), and the morphometric variation in length, width, and weight also could represent the population structure from immature to mature (Syuhaida et al. 2019). All the PW parameters of this specimen $>8 \mathrm{~cm}$ indicated a mature species for both the sexes (Cartwright-Taylor et al. 2009).

The females were not statistically more significant than males, and it is not in line with the morphometric characteristic of $T$. gigas from the other's location (Jawahir et al. 2017; Razak and Kassim 2018). However, this result is similar to the morphometric characteristic of $T$. gigas from Pahang, peninsular Malaysia (Ismail et al. 2012). The weight of these horseshoe crabs increased sharply in the length range of $300-400 \mathrm{~mm}$. In contrast, the increase in the soft body parameters could be a consequence of increased 
food availability and feeding efficiency to the horseshoe crabs (Vijayakumar et al. 2000). The BW-PW relationships showed negative allometric growth for the males. It is in line with previous research on T. gigas in Malaysian waters (Jawahir et al. 2017; Razak and Kassim 2018) and Indian waters (Chatterji et al. 1994).

Variation in morphometric of the horseshoe crabs could be influenced by many factors (Chatterji et al. 1988; Daniels et al. 1998; Gaspar et al. 2000; Graham et al. 2009), including environmental conditions (habitat and waters quality parameters), and the condition's horseshoe crab (the maturity stage, diets, population density, and genetic). In addition, the fat content, eggs present, and exploitation status influenced the matured female weight of T. gigas (Sekiguchi et al. 1988; Razak and Kassim 2017, 2018).

The sex ratio (Table 2) was male-dominated with a small margin (less than 2), suggesting a breeding period more active (Cartwright-Taylor et al. 2009) but not yet indicated seasonal breeding due to males not exceeding females in large number (Carmichael et al. 2003; JamesPirri et al. 2005). The balance of sex ratio suggests this population's health (Cartwright-Taylor et al. 2009). It's one of the essential indicators for horseshoe crab conservation and management. These results will present useful baseline data for monitoring the population structure and growth pattern over the future years.

The lack of recent abundance and density data has caused the IUCN to classify T. gigas as "Data Deficient". This study result was a first step in providing this data gap. For this reason, surveys for monitoring abundance and ecological aspects related to conservation issues need to be pursued, especially in Berbak Sembilang National Park as a conservation area. The findings from the survey support the current conservation status of T. gigas in the Banyuasin estuarine as "Near Threatened". This is due to the difficulty in collecting data for this rare species. Under the National Conservation Status in Indonesia, T. gigas is included in the Protected Marine Biota. For this reason, more encouragement is needed as a protection effort without having to collect more data. The following strategic step is to find nesting activities and breeding sites which we have not found yet.
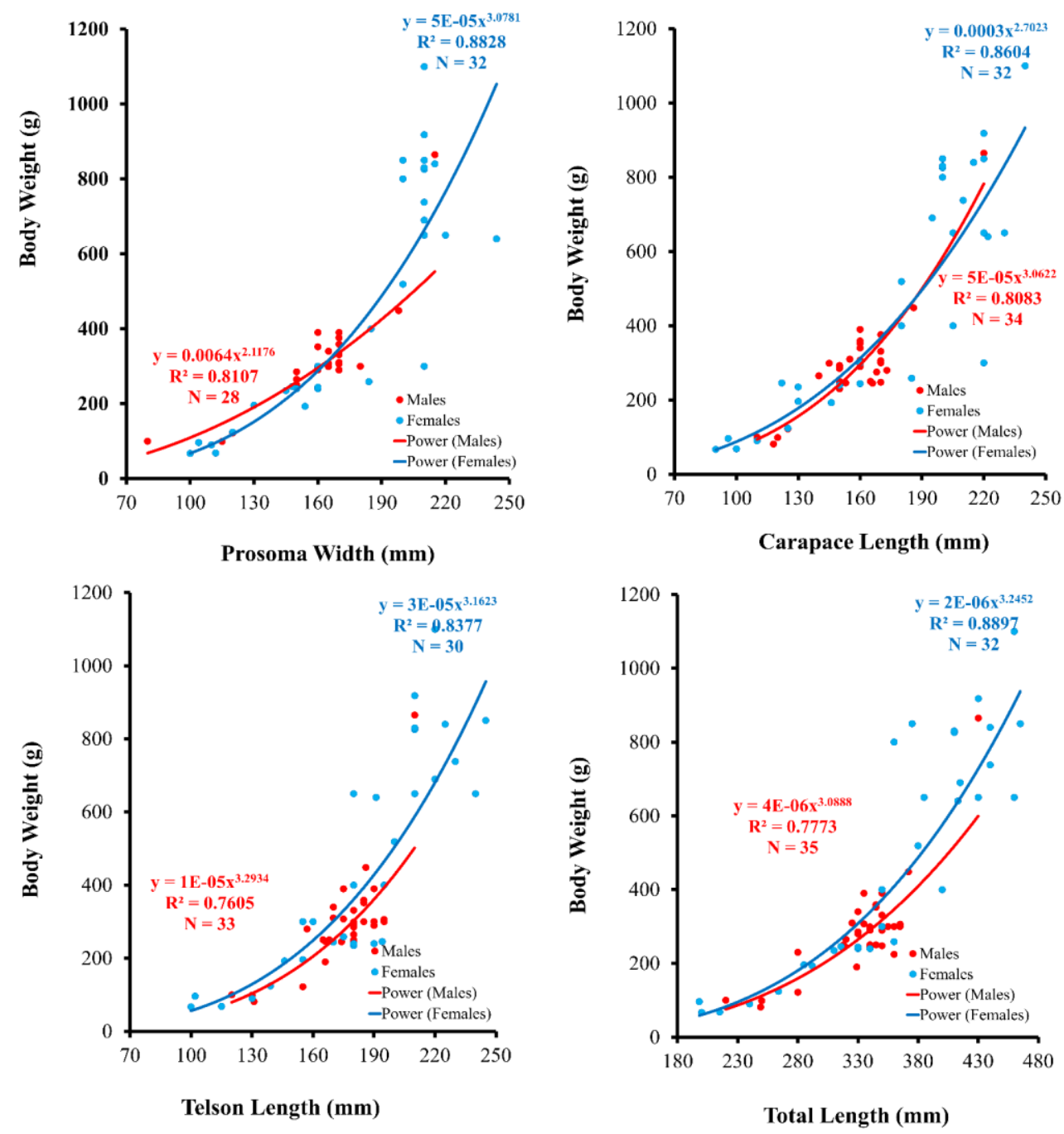

Figure 4. Total weight-length relationship of Tachypleus gigas by sex 

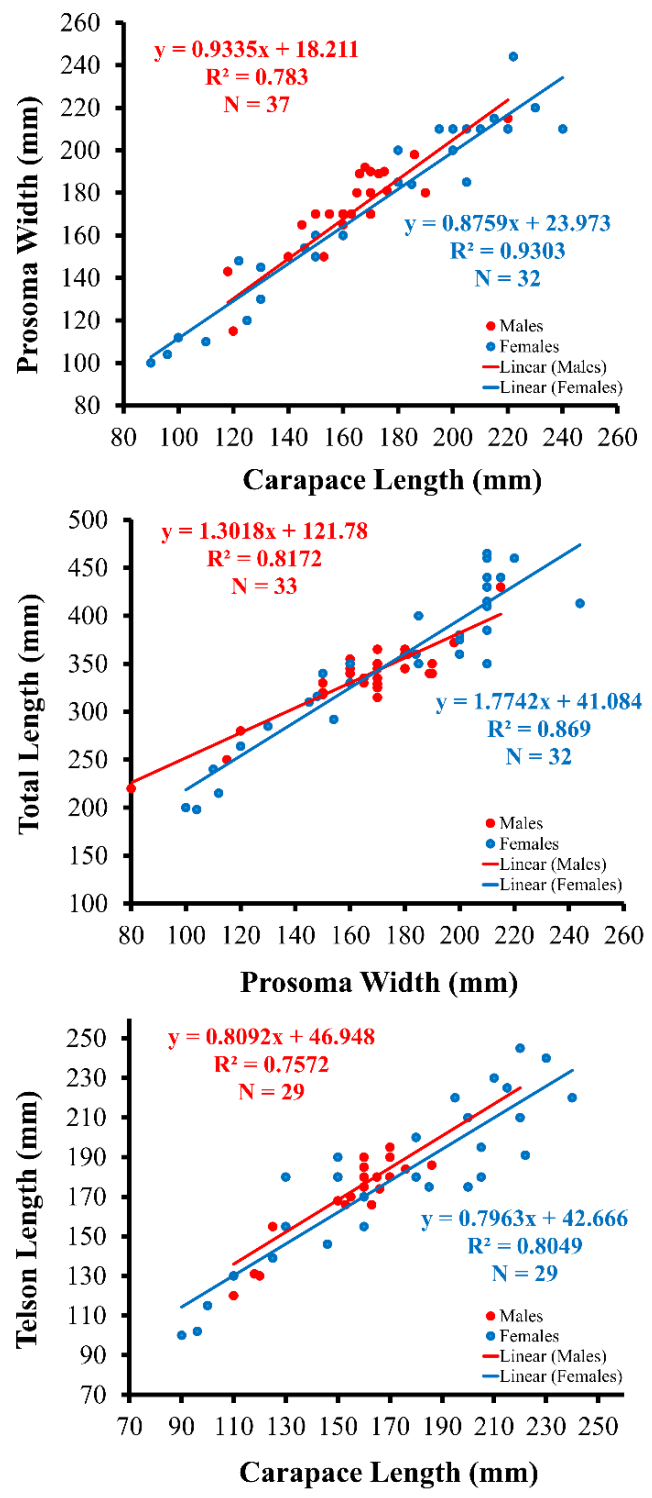

Figure 5. The length-length relationship of Tachypleus gigas by sex

In conclusion, all morphometric characters $(\mathrm{BW}, \mathrm{CL}$, TEL, TL, and PW) had high correlations. The BW was the most significant morphometric character in separating the two sexes. However, there were variations in morphometric characters and growth patterns between the sexes. Therefore, for accuracy in their taxonomic status, genetic analyses are needed.

\section{ACKNOWLEDGEMENTS}

The authors would like to thank Langgeng, Ardani, Saderun, Nita Puspita Sari, Adietya Ramadhan, Dicky Armando, Rahmi, Novrista, and the Banyuasin 2019, 2020, and 2021 crews for their help and collaboration. We are very grateful to the reviewers who provided invaluable suggestions for this paper. And special thanks to the Indonesian Ministry of Research, Technology and
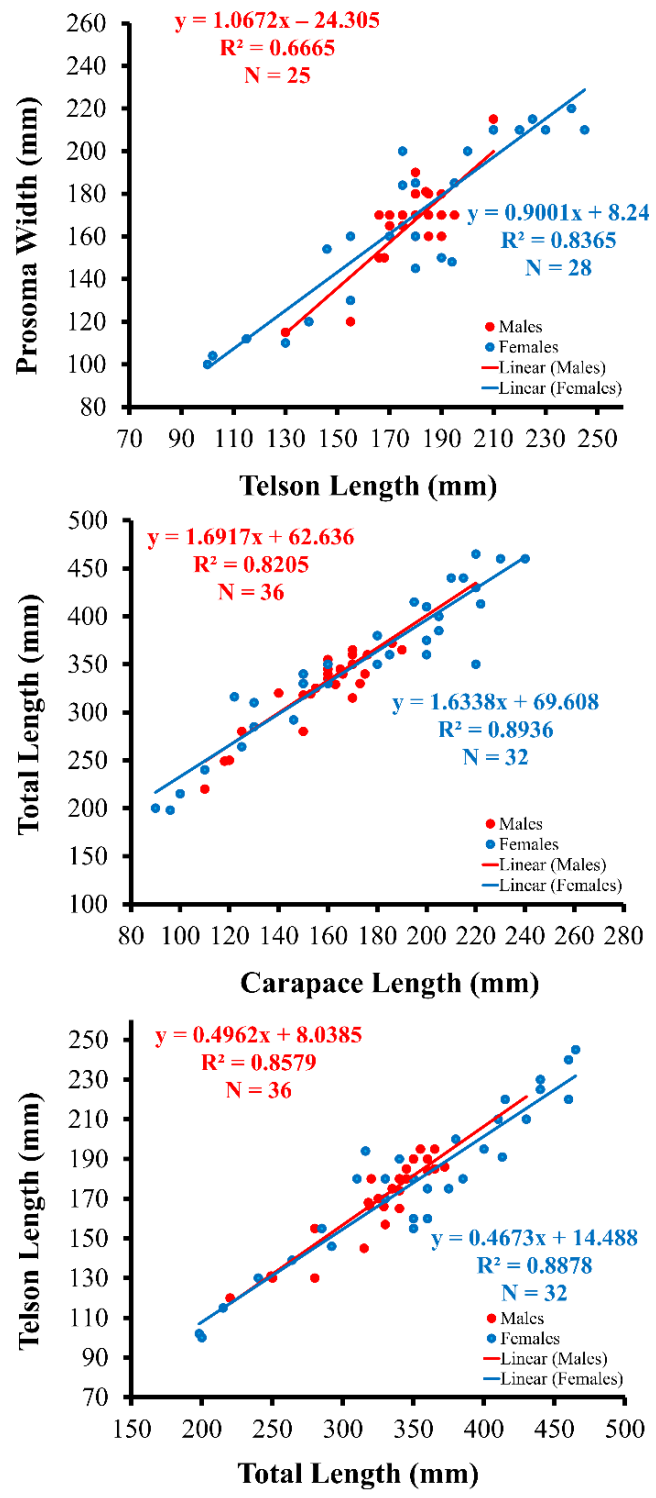

Higher Education for the National Competitive Fund [No. 211/SP2H/LT/DRPM/IV/2019] and [0164.02/UN9/ SB3.LP2M.PT/2021] and Universitas Sriwijaya [SP. DIPA-023.17.2.677515, 2020] and [SP. DIPA023.17.2.677515, 2021] thus, this research has been achieved.

\section{REFERENCES}

Ahmad, Samson SA, Taru P. 2017. Morphometric analysis horseshoe crab from catch result by belat fishing gear in Muara Badak, Kutai Kartanegara Regency. TFS 23: 49-57.

Amaral KDS, Vieira IM, Osório FM, Rocha JDM, Lima JdF. 2014. Bioecology of the crab Ucides cordatus (Crustacea, Decapoda) in mangroves influenced by the Amazon River, Brazil. Acta Amazonica 44: 213-222. DOI: 10.1590/S0044-59672014000200007.

Aydin İ, Aydin C. 2011. Length-length and length-weight relationships in Nephrops norvegicus from the Aegean Sea (Linnaeus, 1758). Mediterr Mar Sci 12: 121-128. DOI: 10.12681/mms.56. 
Biswal GC, Andia BN, Pati S, Dash BP. 2016. Conservation of Indian horseshoe crab, Tachypleus gigas through captive rearing. In: Behera RK, Kariali E, Sahu SK. Frontiers in Life Sciences. Excel India Publishers, New Delhi.

Carmichael RH, Rutecki D, Valiela I. 2003. Abundance and population structure of the Atlantic horseshoe crab Limulus polyphemus in Pleasant Bay, Cape Cod. Mar Ecol Prog Ser 246: 225-239. DOI: $10.3354 /$ meps 246225 .

Cartwright-Taylor L, Lee J, Hsu CC. 2009. Population structure and breeding pattern of the mangrove horseshoe crab Carcinoscorpius rotundicauda in Singapore. Aquat Biol 8: 61-69. DOI: 10.3354/ab00206.

Cartwright-Taylor L, von Bing Y, Chi HC, Tee LS. 2011. Distribution and abundance of horseshoe crabs Tachypleus gigas and Carcinoscorpius rotundicauda around the main island of Singapore. Aquat Biol 13: 127-136. DOI: $10.3354 / \mathrm{ab} 00346$.

Chatterji A, Mishra JK, Vijayakumar R, Parulekar AH. 1994. Lengthweight relationship of the Indian horseshoe crab Tachypleus gigas (Müller, 1785). Indian J Fish 41: 111-113.

Chatterji A, Rathod V, Parulekar A. 1988. Growth and morphometric characteristics in the horseshoe crab, Carcinoscorpius rotundicauda (Latreille, 1802) from Cannning (West Bengal), India. Pak J Sci Ind Res 31: 352-353.

Chiu HMC, Morton B. 2001. Growth and allometry of two horseshoe crab species, Tachypleus tridentatus and Carcinoscorpius rotundicauda (Xiphosura), in Hongkong. Asian Mar Biol 18: 129-141.

Daniels SR, Stewart BA, Gibbons MJ. 1998. Genetic and morphometric variation in the potamonautid river crab Potamonautes parvispina (Decapoda: Potamonautidae) from two Western Cape Rivers, South Africa. J Nat Hist 32: 1245-1258. DOI 10.1080/00222939800770621.

Dolejš P, Vaňousová K. 2015. A collection of horseshoe crabs (Chelicerata: Xiphosura) in the National Museum, Prague (Czech Republic) and a review of their immunological importance. Arachnologische Mitteilungen 49: 1-9. DOI: 10.5431/aramit4901.

Fauziyah, Agustriani F, Putri WAE, Purwiyanto AIS, Suteja Y. 2018 Composition and biodiversity of shrimp catch with trammel net in Banyuasin coastal waters of South Sumatera, Indonesia. AACL Bioflux 11: 1515-1524

Fauziyah, Purwiyanto AIS, Putri WAE, Agustriani F, Mustopa AZ, Fatimah. 2019a. The first investigation record of threatened horseshoe crabs in the Banyuasin estuarine, South Sumatra, Indonesia. Ecologica Montenegrina 24: 17-22.

Fauziyah, Putri WAE, Purwiyanto AIS, Agustriani F, Mustopa AZ, Fatimah. 2019b. The morphometric variability of the mangrove horseshoe crab (Carcinoscorpius rotundicauda) from Banyuasin estuarine of South Sumatra, Indonesia. Ecologica Montenegrina 46: 38-46.

Froese R. 2006. Cube law, condition factor and weight-length relationships: History, meta-analysis and recommendations. J Appl Ichthyol 22: 241-253. DOI: 10.1111/j.1439-0426.2006.00805.x.

Gaspar MB, Santos MN, Vasconcelos P, Monteiro CC. 2000. Shell morphometric relationships of the most common bivalve species (Mollusca: Bivalvia) of the Algarve coast (Southern Portugal). Hidrobiologia 477: 73-80. DOI: 10.1023/A:1021009031717.

Graham LJ, Botton ML, Hata D, Loveland RE, Murphy BR. 2009. Prosomal-width-to-weight relationships in American horseshoe crabs (Limulus polyphemus): Examining conversion factors used to estimate landings. Fish Bull 107: 235-243.

Hegele-Drywa J, Normant M, Szwarc B, Pudluska A. 2014. Population structure, morphometry and individual condition of the non-native crab Rhithropanopeus harrisii (Gould, 1841), a recent coloniser of the Gulf of Gdańsk (Southern Baltic Sea). Oceanologia 56: 805-824. DOI: $10.5697 /$ oc. $56-4.805$

Ismail N, Jolly JJ, Dzulkiply SK, Mustakim MKM, Hafiz ANM, Huda AGI, Taib M, Shamsuddin AA, Chatterji A. 2012. Allometric variations of horseshoe crab (Tachypleus gigas) populations collected from Chendor and Cherating, Pahang, Peninsular Malaysia. J Sustain Sci Manag 7: 164-169.

James-Pirri MJ, Tuxbury K, Marino S, Koch S. 2005. Spawning densities, egg densities, size structure, and movement patterns of spawning horseshoe crabs, Limulus polyphemus, within four coastal embayments on Cape Cod, Massachusetts. Estuaries 28: 296-313. DOI: $10.1007 / \mathrm{BF} 02732863$.
Jawahir ARN, Samsur M, Shabdin ML, Rahim KA. 2017. Morphometric allometry of horseshoe crab, Tachypleus gigas at west part of Sarawak waters, Borneo, East Malaysia. AACL Bioflux 10: 18-24.

John BA, Nelson BR, Sheikh HI, Cheung SG, Wardiatno Y, Dash BP, Tsuchiya K, Iwasaki Y, Pati S. 2018. A review on fisheries and conservation status of Asian horseshoe crabs. Biodivers Conserv 27: 3573-3598. DOI: 10.1007/s10531-018-1633-8.

Le Cren FD. 1951. The length-weight relationship and seasonal cycle in gonad weight I and condition in the perch (Perca fluviatilis). J Anim Ecol 20: 201-219. DOI: 10.2307/1540.

Lee CN, Morton B. 2005. Experimentally derived estimates of growth by juvenile Tachypleus tridentatus and Carcinoscorpius rotundicauda (Xiphosura) from nursery beaches in Hong Kong. J Exp Mar Bio Ecol 318: 39-49. DOI: 10.1016/j.jembe.2004.12.010.

Manimannan G, Salomi M, Priya RL, Saranraj R. 2020. Detecting outliers using $\mathrm{R}$ package in fitting data with linear and nonlinear regression models. Intl J Sci Innov Math Res 8: 1-13. DOI: 10.20431/23473142.0804001 .

Mashar A, Butet NA, Juliandi B, Qonita Y, Hakim AA, Wardiatno Y. 2017. Biodiversity and distribution of horseshoe crabs in Northern Coast of Java and Southern Coast of Madura. IOP Conf Ser Earth Environ Sci 54 (1): 012076. DOI: 10.1088/1755-1315/54/1/012076.

Meilana L, Wardiatno Y, Butet NA, Krisanti M. 2016. Morphological character and molecular identification with COI gene marker of horseshoe crabs (Tachypleus gigas) at coastal waters of Northern Java Island. J Ilmu dan Teknologi Kelautan Tropis 8: 145-158. [Indonesian]

Ming Y, Fujiang D, Xilin DAI. 2016. Length-length, length-weight relationships and condition factor of the giant freshwater prawn Macrobrachium rosenbergii (de Man, 1879) cultured in earthen pond at high density. Asian Fish Sci 29: 164-177.

Mohamed R, Paul NA, Isa NS, Damanhuri JH, Shahimi S, Pati S, John A, Nelson BR. 2021. Using applied statistics for accurate size classification of the endangered Tachypleus tridentatus horseshoe crab. J Ecol Eng 22: 273-282. DOI: 10.12911/22998993/132432.

Nair P, Joseph S, Pillai V. 2015. Length-weight relationship and relative condition factor of Stolephorus commersonii (Lacepede, 1803) exploited along Kerala Coast. J Mar Biol Assoc India 57: 27-31. DOI: 10.6024/jmbai.2015.57.2.01856-04

Nelson BR, Zhong JMH, Zauki NAM, Satyanarayana B, Chowdhury AJK. 2019. Effects of shore sedimentation to Tachypleus gigas (Müller, 1785) spawning activity from Malaysian waters. J Sustain Sci Manag 14: 41-60.

Panda S, Naik PK. 2017. Morphometric study of horseshoe crab (Carcinoscorpius rotundicauda) in Odisha. IJSS J Surg 3: 48-53. DOI: $10.17354 /$ SUR/2017/81

Pati S, Biswal GC, Dash BP. 2015. Availability of Tachypleus gigas (Müller, 1785) along the river estuaries of Balasore District, Odisha, India. Intl J Fish Aquat Stud 2: 334-336.

Pati S, Shahimi S, Nandi D, Sarkar T, Acharya SN, Sheikh HI, Acharya DK, Choudhury T, John BA, Nelson BR, Dash BP, Edinur HA. 2021. Predicting Tachypleus gigas spawning distribution with climate change in Northeast Coast of India. J Ecol Eng 22: 211-220. DOI: $10.12911 / 22998993 / 131244$.

Razak MRM, Kassim Z. 2017. Fishery aspect of horseshoe crab [Tachypleus gigas (Müller, 1785)] in the Peninsular Malaysia: Exploitation status. Univers J Appl Sci 5: 11-15. DOI: 10.13189/ujas.2017.050202.

Razak MRM, Kassim Z. 2018. Comparison of horseshoe crabs (Tachypleus gigas) morphometry between different populations using allometric analysis. AACL Bioflux 11: 143-157.

Rubiyanto E. 2012. Studi Populasi Mimi (Xiphosura) di Perairan Kuala Tungkal, Kabupaten Tanjung Jabung Barat, Jambi. [Thesis]. Universitas Indonesia, Depok. [Indonesian]

Sekiguchi K, Seshimo H, Sugita H. 1988. Post-embryonic development of the horseshoe crab. Biol Bull 174: 337-345. DOI: 10.2307/1541959.

Srijaya TC, Pradeep PJ, Mithun S, Hassan A, Shaharom F, Chatterji A. 2010. A new record on the morphometric variations in the populations of horseshoe crab (Carcinoscorpius rotundicauda Latreille, 1802) obtained from two different ecological habitats of Peninsular Malaysia. Our Nat 8: 204-211. DOI: 10.3126/on.v8i1.4329

Syuhaida N, Rozihan M, Akbar J, Akmal M, Joni H. 2019. Allometry relationship of mangrove horseshoe crab, Carcinoscorpius rotundicauda from the West Coast of Peninsular Malaysia. Intl J Fish Aquat Stud 7: 223-228. 
Tan AN, Christianus A, Shakibazadeh S, Hajeb P. 2012. Horseshoe crab, Tachypleus gigas (Müller, 1785) spawning population at Balok Beach, Kuantan, Pahang, Malaysia. Pak J Biol Sci 15: 610-620. DOI: 10.3923/pjbs.2012.610.620.

Tanacredi JT, Botton ML, Smith DR. 2009. Springer Biology and Conservation of Horseshoe Crabs. Springer, New York. DOI: 10.1007/978-0-387-89959-6.

Thomas S. 2013. Allometric relationships of short neck clam Paphia malabarica from Dharmadom estuary, Kerala. J Mar Biol Assoc India 55: 50-54. DOI: 10.6024/jmbai.2013.55.1.01755-08.
Vijayakumar R, Das S, Chatterji A, Parulekar AH. 2000. Morphometric characteristics in the horseshoe crab Tachypleus gigas (Arthropoda: Merostomata). Indian J Mar Sci 29: 333-335.

Webster M. 2007. A cambrian peak in morphological variation within Trilobite species. Science 317 (5837): 499-502. DOI: 10.1126/science.1142964.

World Conservation Monitoring Centre. 1996. Tachypleus gigas. The IUCN red list of threatened species 1996: e.T21308A9266907.

Yang KC, Ko HS. 2015. First record of tri-spine horseshoe crab, Tachypleus tridentatus (Merostomata: Xiphosurida: Limulidae) from Korean waters. Anim Syst Evol Divers 31: 42-45. DOI: 10.5635/ased.2015.31.1.042. 